УДК 342.9:351.74

DOI https://doi.org/10.32849/2663-5313/2020.4.25

\title{
Дмитро Карбовсъкий,
}

здобувач наукового ступеня кандидата юридичних наук

Науково-дослідного інституту публічного права

\section{ПРИНЦИПИ АДМІНІСТРАТИВНОї ДІЯЛЬНОСТІ ТЕРИТОРІАЛЬНИХ ОРГАНІВ НАЦІОНАЛЬНОЇ ПОЛІЦЇ УКРАЇНИ}

У статті визначено принципи адміністративної діяльності територіальних органів Національної полічії України як основні засади адміністративно-правового регулювання діяльності органів поліиії як суб'єктів публічного права, що визначають спещифіку їхньої адміністративної діяльності, будують інструментарій адміністрування територіальних органів Національної полічії України та встановлюють основи синхронності адміністрування між територіальними органами Начіональної полічії України, іншими правоохоронними органами та органами влади, місцевого самоврядування, а також громадськістю. Визначено, що приниипи діяльності територіальних органів Національної полічії України умовно можна поділити на загальні принципи діяльності територіальних органів Національної поліції України, які встановлюють основи діяльності поліції як правоохоронного органу публічної влади в суспільстві, та спечіальні принципи адміністративної діяльності територіальних органів Начіональної полічії України, що визначають засади адміністрування територіальних органів поліиії всередині системи. Зроблено висновок, що до загальних принципів діяльності територіальних органів Національної полічії України варто віднести: верховенство права та законність; публічність; пріоритет дотримання прав, свобод та законних інтересів особи та суспільства; політична неупередженість і нейтральність; справедливість; ефективність; об'єктивність та незалежність; професійність. До спечіальних приниипів адміністративної діяльності територіальних органів Національної поліиії України належать: територіальність; координація та взаємодія; иілісність; відкритість та прозорість; підзвітність; належне внутрішньо-організачійне адміністрування; належне фінансове та матеріально-технічне забезпечення; приниип вільного доступу до інформащії; застосування фізичної сили чи спеціальних засобів впливу тією мірою, яка необхідна для виконання своїх законних повноважень; дієвість та результативність; відповідальність.

Ключові слова: адміністративно-правове регулювання, внутрішньо-організаційне адміністрування, методи, процедури, статус, форми діяльності.

Актуальність теми. Основу будь-якої діяльності становлять принципи - ті керівні ідеї та уявлення, що закладають основу, фундамент, на якому має базуватися виконання покладених на той чи інший орган завдань та функцій. Відповідно, державноправове регулювання у тій чи іншій галузі підпорядковано принципам, властивим цій сфері. Іншими словами, принципи визначають зміст і спрямованість діяльності як державного органу, так і державного службовця безпосередньо. Принципи відіграють неабияку роль у формуванні і функціонуванні всього державного апарату [8, с. 62].

Частиною державного апарату є поліція. Діяльність поліції у правовому механізмі забезпечення конституційних прав і свобод людини та громадянина складно переоцінити. Саме поліцейські є гарантами використання особою своїх прав і свобод. Завдання, функції, засоби та процедури їх реалізації стосуються практично всіх громадян, визначають обсяг комунікацій, взаємин поліції та народу через систему принципів. Це свідчить про те, що поліція за обсягом, різноманітністю регулюючих, контролюючих, дозвільних і попереджувальних функцій $є$ найбільш диференційованим засобом державної влади і одним із найважливіших елементів правового механізму забезпечення конституційних прав і свобод людини та громадянина в Україні. У правовому механізмі забезпечення конституційних прав і свобод людини та громадянина принципи діяльності поліції становлять складну, цілісну, багатосторонню і багаторівневу систему елементів. Кожен принцип має своє функціональне призначення, за його допомогою провадиться цілеспрямований, результативний вплив на суспільні відносини у сфері реалізації (охорони та захисту) конституційних прав і свобод людини та громадянина [2, с. 171]. 
Тобто принципи діяльності територіальних органів Національної поліції України мають досить специфічну правову природу, що потребує наукового дослідження.

Огляд останніх досліджень. Діяльність органів Національної поліції України з позиції адміністративного права була предметом дослідження багатьох вчених, серед яких: О. Бандурка, О. Батраченко, В. Басс, О. Безпалова, І. Бойко, Д. Власенко, Т. Гаврилюк, В. Галунько, С. Гнатюк, Д. Горбач, В. Грітчіна, С. Діденко, О. Дрозд, Я. Когут, В. Криволапчук, В. Курило, Д. Ластович, Д. Лемеш, М. Лошицький, Н. Максименко, А. Панчишин, О. Проневич, Т. Плугатар, І. Савельєва, В. Тетеря, С. Шестаков, О. Юнін та інші. Проте, оскільки діяльність територіальних органів Національної поліції України $€$ досить вузьким та специфічним науковим аспектом, принципи адміністративної діяльності територіальних органів Національної поліції України є актуальним та своєчасним науковим викликом.

Мета статті полягає в тому, щоб на основі аналізу норм адміністративного права, позицій вчених-юристів, практики діяльності територіальних органів Національної поліції України сформувати та розкрити принципи адміністративної діяльності територіальних органів Національної поліції України.

Виклад основного матеріалу. Юридична енциклопедія визначає принципи як основні засади, вихідні ідеї, що характеризуються універсальністю, загальною значущістю, вищою імперативністю і відображають суттєві положення теорії, вчення науки, системи внутрішнього і міжнародного права, політичної державної чи громадської організації (гуманізм, законність, справедливість, рівність громадян перед законом тощо). Принципам притаманне абстрактне відображення закономірностей соціальної дійсності, що зумовлює їхню особливу роль у структурі широкого кола явищ. Принципи є джерелом багатьох явищ або висновків, що відносяться до нього як дія до причини [11, с. 110].

С. Погребняк припускає, що під принципами права слід розуміти систему найбільш загальних і стабільних імперативних вимог, закріплених у праві, які є концентрованим виразом найважливіших сутнісних ознак і цінностей, що притаманні цій системі права та визначають їі характер, напрями подальшого розвитку. Принципи права $є$ його складником, їм притаманні як загальні ознаки, що властиві праву в цілому, так і ті, що відображають специфіку принципів як особливої юридичної категорії [6, с. 11]. В. Кириченко вважає, що принципи - це основні засади, вихідні ідеї, положення, що відображають зміст права, його сутність і призначення у суспільстві, визначають спрямованість правового регулювання і поширюються на усіх суб’єктів права [4, с. 144].

Своєю чергою А. Колодій зазначає, що принципи права - це такі відправні ідеї його буття, які виражають найважливіші закономірності, підвалини певного типу держави і права, є однопорядковими із сутністю права та утворюють його основні риси, відрізняються універсальністю, вищою імперативністю і загальнозначимістю, відповідають об'єктивній необхідності побудови та зміцнення певного суспільного ладу. Принципи права спрямовують і надають синхронності всьому механізму правового регулювання суспільних відносин, більш досконало розкривають місце права в суспільному житті та його розвиткові. Саме принципи права $€$ критерієм законності та правомірності дії громадян і посадових осіб, адміністративного апарату і органів юстиції та за певних умов мають велике значення для зростання правосвідомості населення, його культури й освіти [ 5, с. 43].

В. Бурденюк визначив, що засади та принципи діяльності Національної поліції України уособлюють концептуальні вихідні положення, які встановлюють основні правила і сутність її організації та функціонування. Реальне покладення в основу діяльності Національної поліції України принципів верховенства права, неупередженості, професійності, гласності, підконтрольності та інших прогресивних засад сприятиме розбудові в Україні інституту сучасної європейської поліції. Значна кількість загальних і спеціальних принципів функціонування Національної поліції України та їх фрагментарне відображення в адміністративному законодавстві актуалізують оновлення та розширене комплексне законодавче визначення системи (переліку і змісту) засад і принципів організації та діяльності Національної поліції України, забезпечення їх дотримання та впровадження у практичну поліцейську діяльність [1, с. 63].

В. Ільницьким удосконалено наукові підходи до визначення принципів адміністративно-процесуальної діяльності органів Національної поліції, під якими слід розуміти основні ідеї, вихідні положення, які закріплені в адміністративно-процесуальному законодавстві, мають загальну значущість, вищу імперативність (веління) і відображають суттєві положення процесуальної діяльності органів Національної поліції [3, с. 3]. 
Як визначив С. Чирик, принципи адміністративної діяльності патрульної поліції взаємозалежні та спрямовані на вирішення головного завдання - створення для громадян і посадових осіб найбільш сприятливих умов для життя, праці, відпочинку, забезпечення потреб, реалізації прав і законних інтересів. Забезпечення особистої безпеки громадян, захист прав і свобод, законних інтересів, запобігання правопорушенням та їх припинення, охорона і забезпечення громадського порядку та інші завдання адміністративної діяльності патрульної поліції можуть бути досягнуті тільки на основі дотримання іï принципів. Сутність принципів адміністративної діяльності патрульної поліції полягає в тому, що вони відображають специфіку іï діяльності, її основні риси, а також загальний характер адміністративної діяльності; підкреслюють головні закономірності, відносини і взаємозв'язки в системі організації та функціонування держави та суспільства забезпечують реалізацію механізму захисту прав і свобод людини та громадянина; становлять основу, на якій здійснюється адміністративна діяльність патрульної поліції [10, c. $164-169]$

Таким чином, принципи адміністративної діяльності територіальних органів Національної поліції України - це основні засади адміністративно-правового регулювання діяльності органів поліції як суб'єктів публічного права, що визначають специфіку їхньої адміністративної діяльності, будують інструментарій адміністрування територіальних органів Національної поліції України та встановлюють основи синхронності адміністрування між територіальними органами Національної поліції України, іншими правоохоронними органами та органами влади, місцевого самоврядування, а також громадськістю.

Закон України «Про Національну поліцію» від 2 липня 2015 року № 580-VIII визначає такі принципи діяльності поліції: верховенство права; дотримання прав і свобод людини; законність; відкритість та прозорість; політична нейтральність; взаємодія 3 населенням на засадах партнерства; безперервність [7].

У процесі нормотворчості, як вказуе С. Чирик, необхідно враховувати наявність як внутрішніх, так і зовнішніх принципів формування i функціонування діяльності Національної поліції України. Це передбачає доцільність введення доповнень до законодавства України щодо інформаційноправових принципів, які б визначали забезпечення підвищення ефективності діяльності поліції. Зазначене, з позиції вченого, стосується таких принципів, як: законність; свобода доступу до інформації; вільне вираження думок і переконань; забезпечення інформаційної безпеки; рівність громадян перед законом; недоторканність приватної власності на інформаційні ресурси (інформаційні продукти та інформаційні технологіï) 3 дотриманням норм авторського права; доступність інформації, що передбачає право кожної людини мати доступ до інформаційних технологій і будь-якої необхідної для неї інформації, дозволеної законодавством для доступу, у будь-який час і в будь-якому місці, недопущення цензури; пріоритет повідомлень про події державної і суспільної значущості та ін. [10, с. 127].

Особливістю природи принципів $є$ їх обов'язковість, всеохоплююча дія, повсякденне дотримання, виконання та втілення в життя законів і підзаконних актів, які регулюють громадський порядок. Також сутність принципів адміністративної діяльності Національної поліції виражається в діяльності уповноважених посадових осіб, громадян, осіб без громадянства щодо вирішення завдань у сфері внутрішніх справ, охорони громадського порядку. Задля цього посадовими особами вирішуються питання, пов’язані 3 функціонуванням системи управління внутрішніми справами, координуванням діяльності учасників суспільних відносин у сфері Національної поліції, організовується робота, контроль і нагляд за ходом її виконання. Значення принципів адміністративної діяльності патрульної поліції України полягає в тому, що вони належать до найзагальніших соціальних орієнтирів, які зумовлюють напрям суспільної поведінки. Принципи $є$ вихідними положеннями для здійснення правового регулювання будь-якої сфери суспільних відносин. Їх можна використовувати за будь-яких умов для вирішення будь-яких завдань. Принципи визначають напрям, практичну організацію та реальне функціонування адміністративної діяльності патрульної поліції. Більше того, принципи адміністративної діяльності патрульної поліції України мають регулятивний характер, завдяки чому набувають значення загальних правил поведінки, які мають загальнообов'язковий характер [9, с. 164-169].

В. Ільницький вказує, що для виявлення специфічних властивостей принципів вони класифікуються на групи за різними ознаками: а) за дією в системі адміністративного права - на загальні, міжгалузеві і галузеві; б) за формою нормативного закріплення - на закріплені Конституцією України і в законодавстві про адміністративно-процесуальну 
діяльність органів Національної поліції; в) за роллю в регулюванні процесуальноправового становища суб'єктів правовідносин - на принципи, які визначають процесуально-правову діяльність органів поліції, та принципи, що визначають процесуальну діяльність осіб, які беруть участь у процесі; г) за предметом регулювання - на принципи організації адміністративно-процесуальної діяльності органів Національної поліції і функціональні - принципи процесуальної діяльності; на принципи, які визначають зміст процесуальної діяльності (верховенство права, взаємодія з населенням на засадах партнерства), і принципи, що визначають процесуальну форму виконання процесуальних дій (безперервність); д) за їх значимістю на фундаментальні (абсолютні - дотримання прав і свобод людини, законність) і конструктивні (відкритість та прозорість, політична нейтральність). Класифікацію принципів можна проводити на змішаній основі, наприклад, за дією в системі права і за формою нормативного закріплення або за предметом регулювання, але найбільш поширена класифікація принципів - за формою нормативного закріплення. Зокрема, вдосконалення законодавства та реформування поліції грунтується на доктрині, базовими засадами якої $€$ повага до прав людини, орієнтованість на слугування суспільству, підзвітність, підконтрольність громадянському суспільству, позапартійність (політична нейтральність), прозорість [3, с. 16-17].

\section{Висновки}

Таким чином, принципи діяльності територіальних органів Національної поліції України умовно можна поділити на: 1) загальні принципи діяльності територіальних органів Національної поліції України, які встановлюють основи діяльності поліції як правоохоронного органу публічної влади в суспільстві; 2) спеціальні принципи адміністративної діяльності територіальних органів Національної поліції України, що визначають засади адміністрування територіальних органів поліції всередині системи.

До загальних принципів діяльності територіальних органів Національної поліції України варто віднести: 1) верховенство права та законність; 2) публічність; 3) пріоритет дотримання прав, свобод та законних інтересів особи та суспільства; 4) політичну неупередженість і нейтральність; 5) справедливість;
6) ефективність; 7) об'єктивність та незалежність; 8) професійність.

До спеціальних принципів адміністративної діяльності територіальних органів Національної поліції України належать: територіальність; координація та взаємодія; цілісність; відкритість та прозорість; підзвітність; належне внутрішньо-організаційне адміністрування; належне фінансове та матеріально-технічне забезпечення; принцип вільного доступу до інформації; застосування фізичної сили чи спеціальних засобів впливу тією мірою, яка необхідна для виконання своїх законних повноважень; дієвість та результативність; відповідальність.

\section{Список використаних джерел:}

1. Бурденюк В. М. Засади та принципи діяльності національної поліції України. Право.иа 2015. № 3. C. 57-63.

2. Гурковський М. П. Основні принципи діяльності поліції щодо забезпечення конституційних прав і свобод людини та громадянина в Україні. Науковий вісник Львівського держсвного університету внутрішніх справ. Серія «Юридична». 2017. Вип. 1. С. 171-184.

3. Ільницький В. О. Адміністративно-процесуальна діяльність органів Національної поліції : автореф. дис. ... канд. юрид. наук: 12.00.07. Запоріжжя, 2017. 22 с.

4. Кириченко В. М., Куракін О. М. Теорія держави і права: модульний курс : навчальний посібник. Київ : Центр учбової літератури, 2010. $264 \mathrm{c}$.

5. Колодій А. М. Принципи права: генеза поняття, класифікація та реалізація. Альманах права. 2012. Вип. 3. С. 42-46.

6. Погребняк С. В. Втілення принципів права в юридичних актах. Вісник Академії правових наук України. 2004. № 2. С. 8-20.

7. Про Національну поліцію : Закон України від 02.07.2015 № 580-VIII. Відомості Верховноі Ради. 2015. № 40-41. Ст. 379

8. Солонар А. В. Принципи діяльності поліції в Україні та за кордоном. Правові горизонти. 2017. Вип. 4. С. 62-67.

9. Чирик С. В. Окремі аспекти поняття та сутності принципів адміністративної діяльності патрульної поліції. Вісник Запорізького начіонального університету. Серія «Юридичні науки». 2015. № 4(1). С. 164-169.

10. Чирик С. В. Правові принципи діяльності Національної поліції України. Інформачія і право. 2015. № 3. С. 123-127.

11. Шемшученко Ю. С. Юридична енциклопедія : в 6 т. Київ: Укр. енцикл., 1998. 672 с. 
The article defines the principles of administrative activity of the territorial bodies of the National Police of Ukraine as the basic principles of administrative and legal regulation of the activity of police bodies as subjects of public law, which defines the specificity of their administrative activity, builds tools for administration of territorial bodies of the National Police of Ukraine and establishes the basis of synchronicity between administrations of territorial authorities bodies of the National Police of Ukraine between other law enforcement agencies and bodies in government, local government, and the public. The principles of activity of territorial bodies of the National Police of Ukraine are divided into general principles of activity of territorial bodies of the National Police of Ukraine, which establish the basics of police activity as a law enforcement body of public authority in the society and special principles of administrative activity of territorial bodies of the National Police of Ukraine, which determine the principles of administration of territorial bodies of the system. It is determined that the principles of activity of territorial bodies of the National Police of Ukraine can be conditionally divided into: general principles of activity of territorial bodies of the National Police of Ukraine, which establish the foundations of the police as a lawe enforcement body of public authority in society; special principles of administrative activity of territorial bodies of the National Police of Ukraine, which define the principles of administration of territorial police bodies within the system. It is concluded that the general principles of activity of territorial bodies of the National Police of Ukraine should include: the rule of law and legality; publicity; priority to respect for the rights, freedoms and legitimate interests of the individual and society; political impartiality and neutrality; justice; efficiency; objectivity and independence; professionalism. The special principles of administrative activity of the territorial bodies of the National Police of Ukraine include: territoriality; coordination and interaction; integrity; openness and transparency; accountability; proper internal organizational administration; adequate financial and logistical support; the principle of free access to information; the use of physical force or special means of influence to the extent necessary for the exercise of their legitimate powers; efficiency and effectiveness; responsibility.

Key words: administrative and legal regulation, internal organizational administration, methods, procedures, status, forms of activity. 